Article

\title{
The Impact of Institutions on the Evolution of Tourism Accommodation Format: Evidence from Wulingyuan, China
}

\author{
Ting Jiang ${ }^{1}$, Shaobing Zhuo ${ }^{2}$, Chaozhi Zhang ${ }^{1,3}$ and Jun Gao ${ }^{1, *}$ \\ 1 School of Tourism Management, Sun Yat-sen University, Zhuhai 519000, China; jiangting610@yeah.net (T.J.); \\ zhchzhi@mail.sysu.edu.cn (C.Z.) \\ 2 Shenzhen Jiuzhoushili Cultural Tourism Development Co., Ltd., Shenzhen 518000, China; \\ zhuoshb@chinatoptown.com \\ 3 Institute of Belt and Road Studies, Sun Yat-sen University, Zhuhai 519000, China \\ * Correspondence: gaoj63@mail.sysu.edu.cn; Tel.: +86-0756-3668279
}

Received: 3 April 2019; Accepted: 14 May 2019; Published: 21 May 2019

\begin{abstract}
This paper examines the impact of institutions on evolution of tourism accommodation format in Wulingyuan, a well-known tourist destination in China, from the perspective of institutional cluster embeddedness. Data were primarily collected through interviews and participant observations. The findings show a five-stage evolution process starting from introduction (1982-1988), through growth (1989-2000), adjustment (2001-2004), and upgrade (2005-2010) to the current stage of individualization (2011-present). During the process, the informal institutions work to suppress, conflict with the formal institutions, yet transform into formal institutions in the end. In such a process, institutional loopholes and frictions are the norm, and tourism accommodation format evolves from extensive development to sustainable development. It suggests that the sustainable development of the tourism accommodation industry needs the synergy of formal and informal institutions.
\end{abstract}

Keywords: format evolution; institutional embeddedness; formal institution; informal institution; tourism accommodation; sustainable tourism development

\section{Introduction}

With the "Opening-up" of China, its economic institution has transformed from a centrally planned mode to a market-based mode, leading to business model change and market segmentation in the tourism accommodation industry. However, problems continue to arise along with the evolution of accommodation formats, such as a lack of crisis planning [1], weak human capital development [2], and low price and profit [3,4]. Institution can be a major factor accounting for these problems [5], whose excessive control over tourism accommodation format may obstruct the upgrade and sustainable development of the sector. For example, institutions obstructed tourism accommodation format development during Russia's post-socialist institutional transition period, the strategies of foreign hotel enterprises were constrained, and the scope of free choices of enterprises were greatly reduced [6]. Such was also the case with the hotel industry of the Victoria colonies of Australia [7]. Yet, apart from the negative impacts that institutions can have on the tourism accommodation industry, institutions may provide a prodevelopment context for innovation [8].

Extant studies are mainly focused on formal institutions and their internal structure, albeit that institutions consist of formal and informal institutions, forming institutional clusters $[9,10]$. In the tourism context, it is argued that sustainable tourism development lies in the joint action of formal and informal institutions [11]. Yet, informal institutions are understudied in the tourism context. Moreover, the structure of the institutional cluster changes over time [10], which may exert different 
impacts on tourism accommodation format at different stages. Nonetheless, most existing research are cross-sectional studies. Therefore, this study takes Wulingyuan, a tourism district located in Zhangjiajie in Hunan Province of China, as a case to explore the impact of institutions on evolution of tourism accommodation format from the perspective of institutional cluster embeddedness. More specifically, this study sets out to (a) investigate the evolution process of tourism accommodation format in Wulingyuan, (b) identify the formal and informal institutions relating to the process, and (c) how the two types of institutions impact accommodation format innovation and its sustainability.

\section{Literature Review}

\subsection{Institutional Cluster Embeddedness}

\subsubsection{Institutional Embeddedness and Institutional Cluster}

Embeddedness was first introduced by Polanyi [12] to analyze the connections between economic actions and social environments. He holds that an economic action cannot exist without social structure, and that it is embedded in both economic and noneconomic institutions. Similarly, Granovetter [13] points out that an economic action is embedded in concrete, ongoing institutions of social relations by criticizing Williamson's use of transaction cost to explain the boundaries of firms. Granovetter's focus on interpersonal ties and the structure of networks contributes to the sociological study of economic life. However, his overemphasis on social relations leads to many controversies [14], because relational embeddedness is not the only form of embeddedness. Zukin and DiMaggio [15] divided embeddedness into four types, namely cognitive, cultural, structural, and political embeddedness. Cultural embeddedness can be understood as informal institutional embeddedness, and political embeddedness refers to formal institutions. Cognitive embeddedness is similar to limited rationality, and structural embeddedness is akin to Granovetter's relational embeddedness [10]. Two of them are institutional embeddedness, which shows the importance of institutional embeddedness as noted by Polanyi [12]. Briton and Kariya's study [16] on Japanese high-end market development, for example, suggests that institutional embeddedness plays an essential role in economic activities.

Institution is a cluster consisting of multiple interrelated institutions [10,17], such as legal rules, political organizations, and cultures [18]. Each institution contains several variables according to vertical or horizontal criteria [19]. For example, legal rules include vertical laws at national, state, and municipal levels, as well as horizontal sector regulations of land control and investment management. In addition to the classification of institutions as legal rules, political organization, and cultures, institutions can also be seen as comprised of formal and informal institutions. Such a typology is widely adopted by researchers [20,21]. Formal institutions are arrangements in organizational structure, while informal institutions refer to value, ideologies, and customs, which are often regarded as endogenetic, nonmandatory, extensive, and sustainable [9]. There are complex structures insides each formal or informal institution, such as compatibility, coupling, frictions, and gaps [10]. Institutional compatibility is the nonconflicting or mutual coordination of goals, and institutional coupling is the functional interconnection and match among institutions. Institutional friction is the opposite of institutional compatibility, while institutional gap is the opposite of institutional coupling. Only institutional arrangements that are consistent and mutually supportive can keep themselves maintainable, otherwise they will become highly unstable [22]. Hence, the institutional cluster can be viewed as the cluster of formal and informal institutions and their respective internal structures. Only by achieving institutional compatibility and coupling of formal and informal institutions can arrangements have the possibility to stay stable and function well.

The relationship of formal and informal institutions can be summarized as complementary [22], conflicting, and substituting [23]. Formal institutions are established based on informal institutions, and formal institutions must be consistent with informal institutions to maintain their stability [24]. Otherwise, agents will choose to follow informal institutions, or even form a group to fight for the leadership and suppress formal institutions. The substitute relationship refers to the transformation 
between formal institutions and informal institutions. Specifically, the transformation of an informal institution into a formal institution occurs with induced institutional changes or mandatory institutional changes; the other way around occurs when a formal institution is abolished but old rules exists [25]. Although extant studies have explored the relationship between formal and informal institutions, they are conducted with a static and cross-sectional approach, despite the fact that formal and informal institutions are both dynamic.

\subsubsection{Framework of Institutional Embeddedness and Institutional Cluster Structure}

Institutional embeddedness has three features that distinguish it from institutional analysis [10]. First, it illustrates actions under the joint functions of rationality and institutions. Second, it enhances the power of institutions in explaining economic actions. Third, it is a multidimensional paradigm that allows the analysis of multiple institutions (e.g., formal and informal institutions, internal, and external institutions) with regard to economic actions. A typical example is the causal model of new institutional economics by Williamson [26], which shows the indirect relationship between institutional environments and individuals. This model not only gives researchers an analytical framework to analyze economic actions from the institutional embeddedness approach, but also implies that actors are self-interested, which is why the model emphasizes governance.

Based on Williamson's framework, Nee [27] puts forward the model for the new institutionalism in economic sociology. It builds the connections among micro-, meso- and macro-levels, allowing the macro institutional environments and microscopic individuals to interact with each other. Specifically, institutional environments at the macro level refer to formal institutions which are under the supervision and implementation of the state. It constrains organizational behaviors through market mechanisms and state management. The network mechanism of enterprises and markets lies at the meso level. Individual action mechanisms derived from social relations and sharing beliefs and norms lie at the micro level. Different from Williamson's emphasis on governance, Nee's model highlights the connected role of organizations. It also encompasses formal institutions in institutional environments and informal institutions embedded in social relations.

Both Williamson's and Nee's models describe how institutions embed in economic actions. Williamson focuses on governance, while Nee adds organizations to the model as a channel to connect institutional environments and individuals. Nee's model seeks to link the micro and macro levels and introduces different organizations that may work at different levels; yet, given that institutional arrangement is a series of institutions, the model fails to detail how these institutions work at the meso level. Furthermore, institutions are in constant change, as are the positions of institutions. They lack the embodiment of dynamic change and stay as a static model, which is the common issue in analysis. These models have been used in tourism studies to discuss the embeddedness of institutions in tourism accommodation industry, and the following section turns to such studies to specify the research gap.

\subsection{Institutional Cluster Embeddedness and Innovation in Tourism Accommodation Format}

The concept of format comes from the Japanese retail industry. In a narrow sense, it refers to the external entity form that consumers can access, corresponding to the concept of store type, store format, or store form. In a broad sense, it includes external entities as well as internal business culture and philosophy; this broad concept of format is adopted in this study. Tourism accommodation format is one element of tourism formats; it is a combination of product form and business form of tourism accommodation [28]. According to the differences between product form and business form [29,30], tourism accommodation format can be divided into star hotels, budget hotels, homestays, hostels, inns, etc. It should be noted that tourism accommodation format is always evolving, seeing a transition from simple to complex format. As is the case with tourism accommodation in North America, it originates from inns and hostelries along the roadside or in main towns. New formats like hotels, guest houses, and boarding houses only emerged after the industrial revolution, while holiday villages, motels, and various self-service accommodation facilities are relatively more recent inventions [31]. 
Institution is a prominent factor in the transformation of the tourism accommodation industry [32-35]. Existing studies, however, tend to emphasize the role of formal institutions, highlighting institutional barriers to the free development of accommodation industry [36-38] and ignoring the cowork of formal and informal institutions. In this regard, it is argued that sustainable tourism development (including its accommodation sector) relies on the joint action of formal and informal institutions [11,39], although how the two types of institutions function together remains unknown. Accommodations are similar to tourism business groups which are also "bound together by persistent formal and informal ties" [40]. Although Karhunen [6] finds different formal and informal rules that work at three development stages of accommodation industry in the former Soviet Union, the interaction of formal and informal institutions is still neglected. Questions like what the formal and informal institutions are and how they influence accommodations evolution need further exploration. Moreover, the institution cluster includes not only the relationship of formal and informal institutions but also their respective internal structures. The two types of institutions mingle with each other to form a complex, dynamic institutional structure that embeds in economic actions.

\section{Methodology}

\subsection{Study Area}

Tourism development in China has long been under the control of government policy and institutional reform [41,42], which makes it an ideal area to explore tourism institutions. Wulingyuan, a district of Zhangjiajie in China, is selected as the specific case (Figure 1). It is located in the central Wuling Mountain of Hunan Province, and is comprised of four scenic areas, including Zhangiajie National Forest Park, Tianzi Mountain Nature Reserve, Suoxiyu Nature Reserve, and Yangjiajie Nature Reserve. Notably, tourism has become the only "pillar" industry of Wulingyuan, accounting for over $90 \%$ of its GDP in recent years. Its accommodation sector mainly caters to tourists on sightseeing and leisure tours.

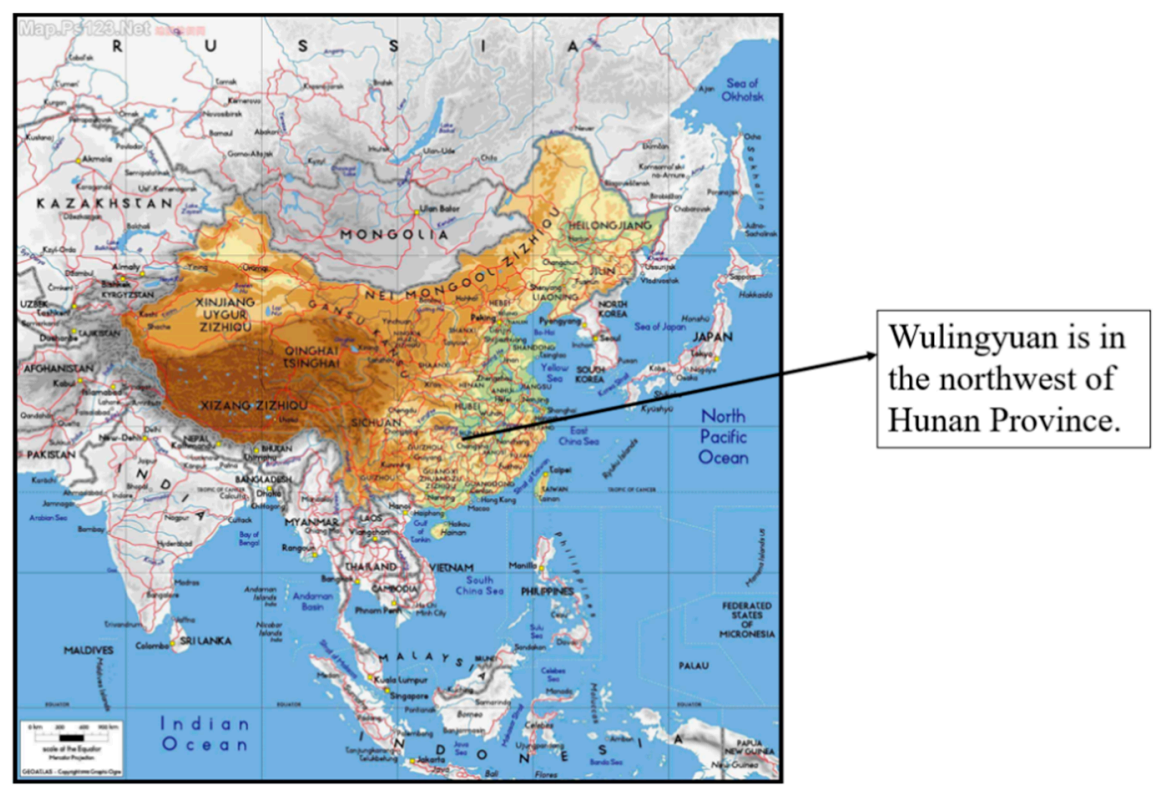

Figure 1. Location of Wulingyuan in Hunan Province, China.

With the modernization reform of China, the accommodation businesses in Wulingyuan have undergone major changes embedded in wider social, economic, and political contexts over nearly four decades. Growing from only one guest house in 1981 to 161 hotels, restaurants, and guest houses in 2000, and to 419 star-rated hotels, social hotels, homestays, and inns in 2016, the accommodation sector there has significantly upgraded and diversified within a relatively short period of time along with 
Wulingyuan's rapid tourism development. Yet, the unprecedented growth has also exerted much pressure on its environment and resources. Wulingyuan constitutes a focal point for this study because: (a) tourism accommodation format there has undergone rapid changes and consequently features much diversity; (b) the area is highly dependent on tourism, hence tourism factors are more observable; (c) as a World Heritage Site, Wulingyuan has attracted attention from multiple stakeholders (e.g., local government, international organizations, social groups), resulting in abundant institutions at different levels.

\subsection{Data Collection}

Considering the exploratory nature of the research, a qualitative approach was adopted [43]. Data were mainly collected during 3-14 August 2015, and supplementary data were collected during 15-20 January 2016. Notably, before the research was conducted, the authors had been to Wulingyuan several times and known the accommodation industry very well by communicating with local government and enterprises regularly.

Semistructured interviews and observations were adopted for data collection. Interviews were conducted with a snowball sampling approach. In total, ten government officials, 44 hotel owners, and 19 tourists were interviewed. For government officials, the questions were mainly related to changes in regulations of accommodation industry and their attitude towards accommodation format evolution. For hotel owners, the questions were mainly focused on product forms and business forms of tourism accommodation and critical events motivating the transformation of the accommodation sector. Moreover, tourists were asked about their demands and comments on accommodation facilities. Each interview duration ranged from 20 to 120 minutes, and over 3500 lines of Mandarin text were recorded. Meanwhile, observation notes including basic information of location, decoration style and scale of accommodation facilities were taken. Numerous secondary sources of data, such as government regulations, working documents, and statistics, were obtained to complement as well as triangulate the first-hand data.

\subsection{Data Analysis}

Text analysis was utilized for data analysis. Through the concept analysis, understanding of the meaning of communication is deepened and key processes are identified. The analyzed results are closely related to the meaning, purpose, result, and context of the text [44].

The analysis went through three stages (Table 1), and NVivo 11 was adopted to assist the coding process. First, the text was open-coded. Each sentence was labeled through repeated reading, resulting in 97 open codes. Second, 97 open codes were compared to identify the connections among them, and 14 axial codes emerged. Third, the 14 axial codes were then grouped into four core categories, that is, accommodation format, formal institution, informal institution, and institutional embeddedness. Through such a rigid process, the authors managed to establish logical relationships and concept networks, and sort out the main agents, driving factors, and operational mechanisms behind the evolution of tourism accommodation sector in Wulingyuan. 
Table 1. Coding process.

\begin{tabular}{|c|c|c|}
\hline Main Category & Axial Coding & Open Coding \\
\hline $\begin{array}{l}\text { Accommodation } \\
\text { Format }\end{array}$ & $\begin{array}{l}\text { star hotel format } \\
\text { social hotel format } \\
\text { family hotel format } \\
\text { youth hostel format } \\
\text { inns format }\end{array}$ & $\begin{array}{l}\text { Standardization, diversified styles, complete function, state-owned, green ecology, } \\
\text { diversified profit models } \\
\text { Upgrade and renovation } \\
\text { illegal construction, individual investment, inns-like, backward design, backward } \\
\text { facilities, illegal construction, spontaneous renovation, rental management } \\
\text { shared room, young people, travel on a budget } \\
\text { not pure, individualized service, small scale, frequent interaction, home feeling, } \\
\text { chain management trend, cultural carrier, distinctive themes }\end{array}$ \\
\hline $\begin{array}{c}\text { Formal } \\
\text { Institution }\end{array}$ & $\begin{array}{l}\text { laws and regulations } \\
\text { industry regulations }\end{array}$ & $\begin{array}{l}\text { international organizations, protection regulations, planning constraints } \\
\text { family hotel management regulations, inns management regulations, travel agency } \\
\text { management regulations, green hotel regulations, social hotel management } \\
\text { regulations, star system regulations } \\
\text { City renewal, local tourism development planning, local tourism reform, electricity } \\
\text { discount, high-end hotel orientation, advocating family hotel construction, official } \\
\text { business spending limit, promoting tourism development by state, state guidance, } \\
\text { financial support, market economy, vacation institution, investment promotion and } \\
\text { capital introduction, locals' livelihood strategies, investigation and learning, leading } \\
\text { construction }\end{array}$ \\
\hline $\begin{array}{l}\text { Informal } \\
\text { Institution }\end{array}$ & $\begin{array}{l}\text { concept } \\
\text { spontaneously } \\
\text { industry } \\
\text { organizations } \\
\text { demonstration and } \\
\text { imitation } \\
\text { cultural elite }\end{array}$ & $\begin{array}{c}\text { service culture, architectural characteristics, inn culture, national culture, mountain } \\
\text { culture, cultural differences, cultural integration } \\
\text { backward ideas and concepts, inns nostalgia, lack of foresight, balance between } \\
\text { business and nostalgia, social trends, lifestyle, peasant thinking, leisure tourism, idea } \\
\text { changes of tourists, idea changes of government } \\
\text { hotel alliance }\end{array}$ \\
\hline
\end{tabular}

\section{Results}

\subsection{Tourism Accommodation Format Evolution in Wulingyuan}

\subsubsection{Phase One: Introduction (1982-1988)}

The establishment of the National Forest Park in 1982 marked the beginning of this stage. Tourism development motivated the construction of accommodation facilities. Poor facilities, such as guest houses, mountain villas, and sanatoriums, were the main formats. Most accommodations were constructed by local government, state-owned corporations, or troops due to the lack of finances and capabilities among ordinary social stakeholders. The first construction peak appeared along with large amount of land allocated for development. At the time, tourism accommodation facilities were in the hands of local government rather than market forces.

\subsubsection{Phase Two: Growth (1989-2000)}

The establishment of Wulingyuan Scenic Spot in 1988 integrated the development of previous three separate administrative areas, namely, Zhangjiajie National Forest Park, Suoxiyu Natural Preserve, and Tianzishan Natural Preserve. This, in turn, helped to deal with the contention for resources, projects and funds among different administrative regions, impelling a significant boost in tourism accommodation facilities. State-owned enterprises increased investments during the 1990s, 
augmenting the number of accommodation facilities in core scenic areas and transforming the product form from economic to high-end, luxury, and grouping type. According to the statistics of Wulingyuan Tourism Administration, among the 161 accommodation facilities, there were 14 star-hotels. Thanks to the implementation of the star-hotel standard in 1997, tourism accommodation format became standardized and achieved enterprise operation gradually. Nevertheless, the nationwide marketization of state-owned enterprises and the stagnation of China's hotel industry development were a major blow to the tourism accommodation sector in Wulingyuan. This made some state-owned hotels redundant and resulted in the separation of ownership and management, such as the closure of Huadian Hotel and Wulingyuan Hotel in 1994. Meanwhile, the excessive amount of tourism facilities made Wulingyuan become an "island" besieged by tourism, seriously damaging its environmental biodiversity and aesthetic value of nature.

\subsubsection{Phase Three: Adjustment (2001-2004)}

This phase began with the relocation of residents in core scenic area of Wulingyuan and the pass of "Regulations on the Protection of World Natural Heritage of Wulingyuan in Hunan Province" in 2000. To protect the natural heritage as requested by upper level governments as well as UNESCO, two large scale relocations were launched in 1999 and 2001, respectively, 59 accommodation facilities removed and 1,130 residents relocated. In such a process, due to limited financial capability of the local government, some residents were relocated to hidden places of the heritage area (so as not to be spotted by inspections of upper level governments and UNESCO). This caused further problems as would be noted later. The relocation was caused by conflicts between heritage protection and utilization, but provided an opportunity for the unified planning of family hotels. With the upgrade of tourism accommodation facilities, decoration upgrading and star-hotel building were prevailing at this stage. On the other hand, private enterprises became the mainstay of investments which resulted in the existence of multiple ownership forms of tourism accommodation. This phase also showed that state-owned hotel institutions stagnated, and that the rapid emergence of family hotels caused price competition and conflicts between economic development and heritage protection.

\subsubsection{Phase Four: Upgrade (2005-2010)}

This phase began with the second round of hotel upgrade in 2005. After 20 years of development, the structure of accommodation formats was stabilized. In terms of product form, large numbers of high-star hotels appeared and low-end accommodation facilities operated by local residents declined. Regarding business form, international standards were achieved by introducing or signing management contracts with international hotel groups. Also, online agents started to replace traditional travel agents, which greatly extended hotel supply chains [45]. The involvement of foreign capital during this period accelerated the upgrade and scale development of accommodation industry, leading to the development towards informationization, personalization, and customization.

\subsubsection{Phase Five: Individualization (2011-Present)}

The emergence of new accommodation formats such as inns and youth hostels in 2011 marked the beginning of this stage. Format innovation has been active, and hotel apartments, themed hotels and motels are gaining popularity. The product form shows an individualized, high-end, and leisure-oriented trend, while the business form relies on industrial chain, mobile payment, and word-of-mouth communication. This new stage features the existence of multiple formats and a decrease in star hotels, demonstrating the new trend in leisure vacation and market segmentation. The characteristics of the accommodation sector of Wulingyuan during each phase are summarized in Table 2. 
Table 2. Five stages of tourism accommodation evolution in Wulingyuan.

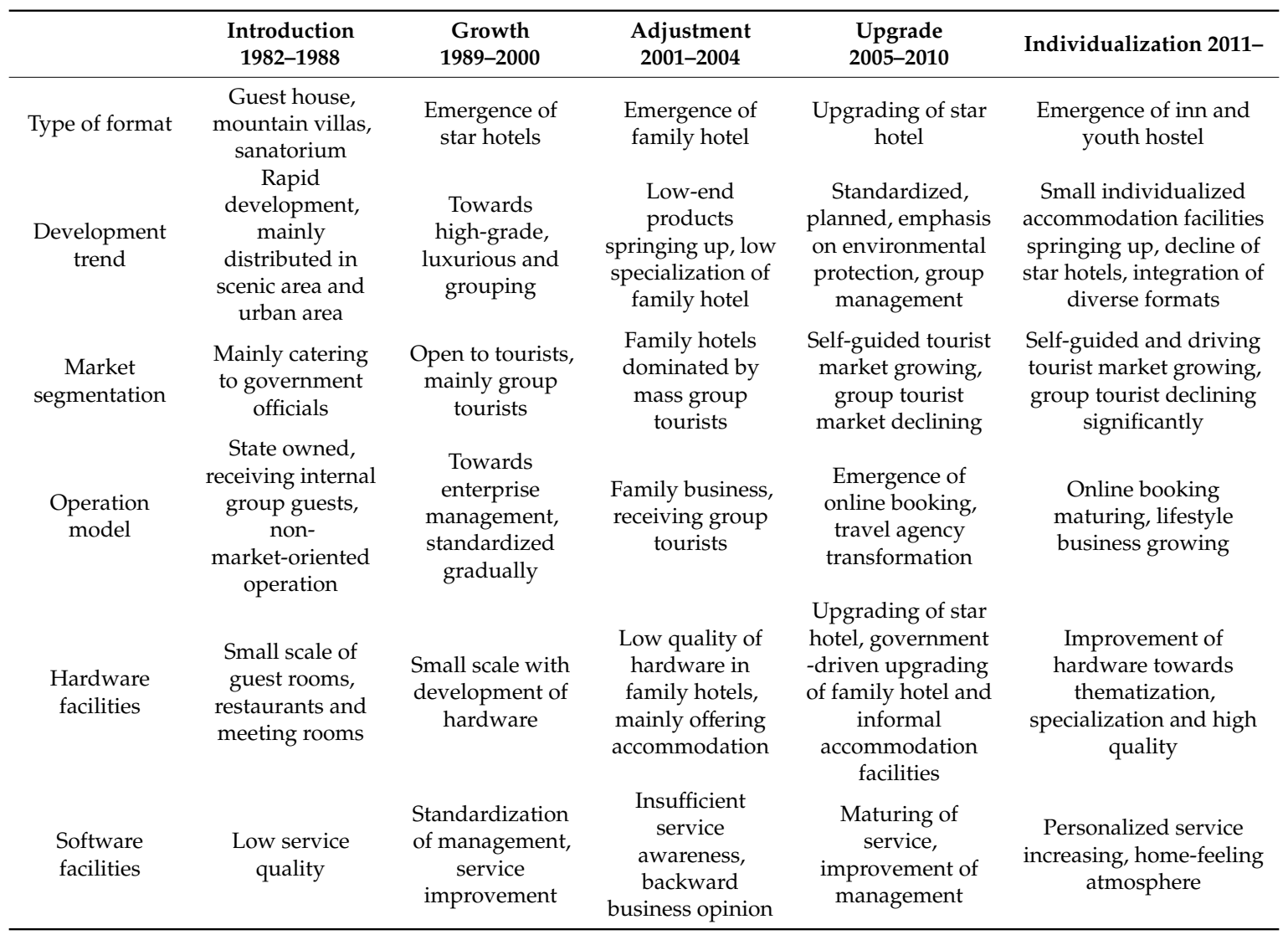

\subsection{Formal and Informal Institutions within the Destination}

Formal institutions in Wulingyuan were written institutions formulated by governments, including policy documents, legal norms, and industrial regulations. Specifically, policy documents were policies issued by different levels of governments covering commercial loans, national annual leaves, tourism, and accommodation development direction, etc. They provided financial support, increased consumer demand, and adjusted the structure and proportion of tourism accommodation format, just as one local official (Z01) said:

"Government officials are forbidden to stay at five-star hotels during business travel according to current national regulations. This helps to bring back the rationality of tourism market. Tourism market used to be irrational, because the government paid for officials' travel cost and caused high price of accommodation facilities. Although it suppresses the construction of high-end hotels now, it fosters the recovery of mid-range hotels".

Legal norms included conventions of international organizations, regulations, and planning documents promulgated by governments. A typical example was the "Notice of Zhangjiajie National Forest Park Protection Scenic Area" issued by Zhangiiajie National Forest Park Management Office in 1985 to restrict constructions in scenic areas. Industry standards were the standards and norms of star-hotels, social hotels, as well as green hotels.

Comparatively, informal institutions referred to meaningful unwritten social operating rules, such as regional culture, concepts, and tourism culture elites. Regional culture included local architectural culture, mountain culture, and ethnic culture, which was the expression of local context [46]. One hostel operator $(\mathrm{Q} 25)$ commented on local culture as follows:

"The west part of Hunan is characterized as tough. You know that there were many bandits

here. Many people might want to come here, but they dared not to come". 
Concepts referred to tourism development concepts of the government and business entities. Tourism culture elites' entrepreneurship helped to create new accommodation formats with local features. For example, one local inn operator (K51) recalled:

"When we planned to do this (inn), we went to Lijiang. We liked the local customs and practices there very much. We could feel the special way operators get along with guests. We thought that we could have a local version of inn in Wulingyuan. So, when we came back, we started it [with cultural features of Wulingyuan area]".

\subsection{Institutional Embeddedness in Tourism Accommodation Format Evolution}

\subsubsection{Introduction Phase (1982-1988): Informal Institutions' Suppressing of Shadow Formal Institutions}

Although the Reform and Opening-up Policy had been implemented for a while, the ideas of traditional small-scale peasant economy were still prevalent in Wulingyuan. This disturbed the spread of formal institutions like tourism accommodation development policies. Some even held the view that tourism was the pursuit of "bourgeois lifestyle" and the introduction of foreign capital betrayed national sovereignty. Formal institutions in Wulingyuan lacked cultural foundations, so the local government implemented a set of conservative administrative institutions within planned economic institutions and missed the opportunity from "Notice on the Relevant Issues Concerning the Use of International Commercial Loans for Self-built Tourist Hotels" by the state council in 1986. It faced potential overembeddedness [47] of informal institutions. In this regard, one inn employee (K34) said:

"The new culture brought by tourism in the 1980s conflicted with local culture. That is, local ethnic culture battled with the advanced culture from outside. The harmonious co-existence of these two needed time. The government introduced policies to control the situation, but it was not easy".

\subsubsection{Growth Phase (1989-2000): Constant Rubbings between Informal and Formal Institutions}

Differences between formal and informal institutions and the existence of loopholes and frictions in formal institutions led to disorder in the accommodation industry. After "thought liberations" at the introduction stage, the development of accommodation facilities in Wulingyuan was finally recognized and supported by stakeholders. State-owned and collective investments grew rapidly, which set off the climax of accommodation facilities' construction. However, formal institutions yielded to the logic of economic development, and stayed unimplemented as shallow institutions. It could be illustrated by the fact that during the period of 1993 to1998, the planning of "adjusting Tianzi Mountain, exploiting Yejipu compressing Luogu Tower and developing Jundiping" to reduce environmental pressure of the heritage zone, existed in name only, and that opportunistic tendency motivated actors to invest mainly for benefits. Furthermore, overlapping management led to frictions of formal institutions among different administrative departments, and the existence of institutional loopholes and frictions further weakened the authority of formal institutions. The Convention for World Cultural and Natural Heritage Protection was not well implemented by local authorities, which created an "institutional vacuum". Consequently, investors and operators could simply ignore the Convention, and accommodation facilities bloomed everywhere in the core area of the heritage site. The overuse of natural resources and the negative impacts on the environment threatened the holistic, integrated and participative development of Wulingyuan [48]. The situation was not changed until Wulingyuan was given a yellow-card warning by World Natural Heritage Committee in 1998.

4.3.3. Adjustment Phase (2001-2004): Informal Institutions Dominated by Internalized Formal Institutions

Formal institutions of local government achieved institutional de-embedding and re-embedding by aligning with upper institutions, which temporarily suppressed informal institutions. There were 
two major changes in external formal institutions at that time. One was the national encouragement of low-end accommodation construction in response to the Golden Week in 2000; the other was the promulgation of "foreign-related tourism hotel star rating" in 1997. In order to foster the compatibility and coupling between internal and external formal institutions, local government took corresponding measures immediately. The first was to implement the relocation of residents in the scenic spot under the model of "building a family hotel and tourism community with high standards in other areas". The second was to introduce standards supporting policies for star hotels, such as promulgating normative documents, formulating supporting planning and management systems, and carrying out special tourism market rectification activities. For example, one government official (Z05) noted:

"The transformation of state-owned hotels was conducted around 2002, and evaluated in 2003. Because China introduced a policy to give star hotels a price concession at that time. Electricity price concessions have greatly increased the enthusiasm of rating stars".

Under the joint constraints of UNESCO, state and local governments, the 18th session of the Standing Committee of the Ninth People's Congress of Hunan Province passed "Wulingyuan World Natural Heritage Protection Regulations" in 2000, which was the first unambiguous formal institution of the accommodation industry. It verified the success of local formal institutions' embeddedness at this stage.

4.3.4. Upgrade Phase (2005-2010): Informal Institutions Breaking through the Stagnation of Formal Institutions

Mandatory local formal institutions could temporarily regulate accommodation formats, but it was difficult to follow the changing upper institutions in time. The failure to catch up with upper institutions obstructed the development of the accommodation sector, as an official from local tourism administration (Z02) noted:

"Star hotels used to have preferential treatment on electricity. Therefore, their enthusiasm of ranking star is relatively high. But the treatment was cancelled two years ago due to the constraint imposed by national government. Now there are only 40 star-hotels in Zhangiajie, whereas in 2003 it was over 60".

Because of the inconsistency between lower-lever institutions and upper-level institutions, lower-level institutions lost authority and failed to embed in local accommodation formats. The absence of new institutions and the frictions of original formal institutions led to the disorder in accommodation formats again. The issue of overlapping management stood out, as a local official (Z10) pointed out:

“The management office inside the scenic spot can be separated as Tianzishan Office and Yuanjiajie Administrative Committee. Tianzi Mountain belonged to Wulingyuan and Yuanjiajie belonged to Zhangjiajie National Forest Park Management Office. While the above two agencies have been merged this year, the personnel and property are still not unified, which causes some problems".

On the other hand, the aforementioned concealed relocation laid a hidden danger for format development. These relocated residents started to receive tourists by rebuilding and expanding family hotels, and these "illegal" accommodation facilities continued to expand in the scenic area. The thought of "economy first" motivated agents to take risks and constantly broke through the constraints of formal institutions. For example, one official from a local heritage protection authority (Z07) noted:

“There are business opportunities now, but the government does not allow residents to engage. The government closely monitors the entrance gates, and the building materials are not allowed to be shipped in. Yet, the residents take many measures to cope with it. They put the cement and bricks at the bottom of trucks and put vegetables and rice on top to disguise these building materials, or use horses to ship the materials into the scenic area via 
"small tracks". In addition, they can also get building materials from the construction team certificated by local government with high prices. We use armed polices to guard the gates and send out a fire squadron, but it cannot be completely banned".

\subsubsection{Individualization Phase (2011-Present): Informal Institutions' Transforming into} Formal Institutions

Formal institutions cannot regulate agents' behaviors and prevent possible opportunism due the existence of institutional defects, and acquiescence was adopted by local government. This, however, objectively provided a benign development environment for new formats. The emergence of inns offered an opportunity to promote tourism transition from sightseeing to leisure travel in Wulingyuan, which matched the expectation of local government.

Besides, civil society organizations became a communication channel between individuals and local government. The Travel Inn Branch of Zhangjiajie Tourism Association was established on 10 May 2016, providing a platform for information sharing among tourism culture elites and promoting the aggregation and accumulation of informal institutions. The aim of the association is to unify, speak for, and improve the status of inns, guiding the government to understand the importance of inns in leisure travel development of Zhangiajie. The entrepreneurs from the association pioneered leisure-oriented format innovation, as one of them (K33) commented:

"In 2014, Wulingyuan renovated villages in the city. There were many small hotels left over from the past. We did not know how to rebuild them. At that time, Yuandi Inn and other inns set a good example for us. Some local people came to visit and these inns strengthened their confidence".

Furthermore, local government officials went out to learn experiences from places where accommodation facilities were well developed to standardize accommodation formats in Wulingyuan. The prevailing informal institutions helped the local government to undertake its role as a reformer. It transformed informal institutions into formal institutions and got rid of institutional vacuum by promulgating "Implementation Measures for the Construction and Management of Rural Characteristic B\&B (Inn) in Wulingyuan District of Zhangjiajie City" in March 2016.

\section{Discussion}

This study investigates the impacts of institutions on the evolution of tourism accommodation format in Wulingyuan from the perspective of institutional cluster embeddedness. It reveals that during the five-stage evolution of its accommodation sector, the relationship between informal and formal institutions has gone from suppression, to conflict, and to complementarity (Figure 2). Suppression was the norm during the first two stages of accommodation format evolution, when informal institution was deeply rooted in the thoughts of residents. The situation did not change until local formal institutions adopted mandatory measures to maintain their effectiveness by fitting with upper institutions. However, compulsory measures adopted by local authorities caused consistent conflicts between formal and informal institutions at the adjustment (2001-2004) and upgrade (2005-2010) stages. Upper-level institution changed so fast that local formal institutions could not catch up with it. Gradually, the constraints of local formal institutions on informal institutions lost efficacy due to the reappearance of institutional loopholes and friction. With the information transfer by entrepreneurs, informal institutions broke through the restriction of formal institutions and achieved synergy with formal institutions. 


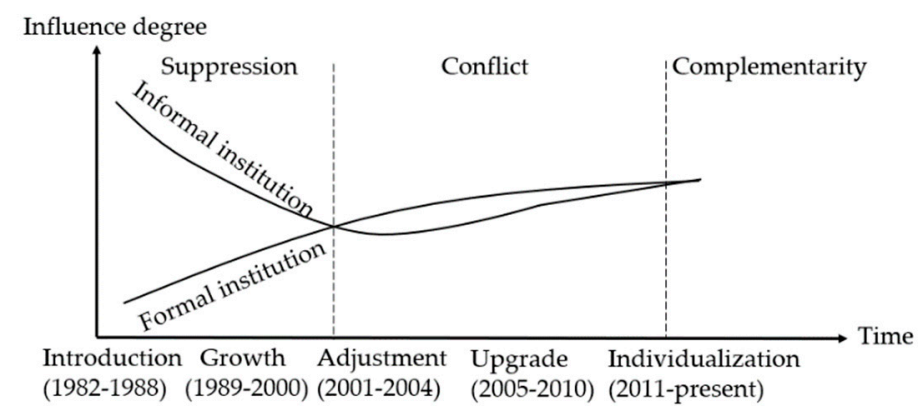

Figure 2. Relationship between formal and informal institutions in the evolution of Wulingyuan tourism accommodation format.

There are two transition nodes regarding the interaction between formal and informal institutions. The first transition node lies at the adjustment stage. Compared with formal institutions, informal institutions had a stronger historical continuity and a lower marginal cost, and individuals tended to choose them instead of formal institutions to conduct a transaction. Hence their speculative behavior in Wulingyuan was skyrocketing regardless of damages to environment and economic sustainability. With the coercive force of upper institutions, local government temporarily concealed institutional loopholes and friction, and formal institutions were able to compete with informal institutions. Obviously, the appearance of the first transition node can be attributed to internal changes in formal institutions, while the second transition node played out due to entrepreneurs' efforts. Entrepreneurs function as a strong engine for growth during economic transition periods [49]. Wulingyuan's highly tourism-dependent economy means that entrepreneurs are more likely to obtain profits from tourism-related businesses, which motivates them to share profit opportunities with local government to promote tourism development at the destination level. This, in turn, helps expand their business opportunities. They introduced the concept of new accommodation formats and expanded the range of options for formal institutions with low transaction cost, which promoted development principle changes of local government and gained legitimacy for informal institutions. In short, benefits that can be made by expanding certain rules help to transform informal local rules into generic ones [50]. As Lin [25] argues, the profit opportunity generated by institutional imbalance is an important cause of induced institutional change. When original institutional arrangement cannot provide the condition for individuals to obtain these profits, the desire for benefits motivates them to negotiate and bring about coalition reshaping [50]. Notably, while some researchers argue that accommodation enterprises are often "bystanders lacking the capacity or motivation to promote institutional change" [40,51], these inns, hotels, and homestays in Zhangiajie function as de facto agents who introduce new market-enhancing rules and procedures. That said, the tourism accommodation industry could obtain a beneficial formal institutional arrangement by creating and sharing profit opportunities among stakeholders.

According to Nee, the institutional cluster embeddedness functions at macro, meso, and micro levels (Figure 3) [27]. Institutional environments lie at the macro level, and individual actions lie at the micro level. The organization field is a meso platform, where the interactions between the macro institutional environment and micro individuals action play out. The relatively concrete form of organization, such as enterprises, helps to present what the structure of institutional cluster is and how it functions in tourism accommodation format updating. Regarding the embeddedness of institutional clusters, two things of this study stand out from Nee's original model. First, dynamic institutional clustering lies at the meso level, where the interactions between formal and informal institutions plays out. Local formal institutions need to rely on compulsory power endowed by formal institutions at the national level to contend with local informal institutions, since institutional loopholes and frictions exist in formal institutions. Otherwise, local formal institutions would face disembeddedness. Local informal institutions (e.g., business concept) is constantly impacted by external cultures, and they promote the evolution of format mainly by imitation, learning, and innovation. Hence, the argument 
that the relationship between formal and informal institutions is linear (e.g., the linear transformation of informal institutions into formal institutions) [52], is not borne out by this study. Instead, these two types of institutions interact with each other to achieve a dynamic equilibrium by continually attempting to embed in institutional clusters. Second, individuals' rational choice runs through the whole process of institutional cluster embeddedness. It is, however, limited rationality, which means agents do not have enough knowledge of "the rules of the game" or the power to make perfect choices, and they usually rely on their shared perceptions to achieve equilibrium and facilitate coordination [22]. That is also the reason why formal institutions exist. Formal institutions complement the shortcomings of informal institutions and meet individual actors' demand for potential profit opportunities. Thus, tourism accommodation format evolution results from the joint effect of rational choice and institutional cluster constraints.

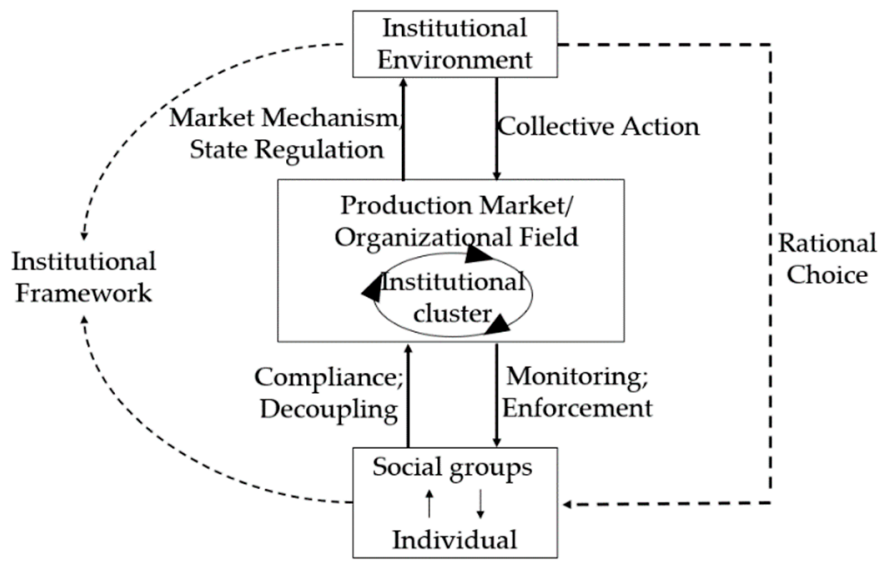

Figure 3. Institutional cluster embeddedness of tourism accommodation format. Note: adapted from Nee's model [27].

Thanks to the embeddedness of institutional clustering, the tourism accommodation industry in Wulingyuan has experienced transformations as follows: It has shifted from a state-dominated sector to a market-based sector; regarding the subjects of accommodation format supply, private enterprises have gradually become main players in the supply chain; in terms of development logic, increasing attention has been paid to heritage protection. Institutional cluster embeddedness has played a significant role in transforming the tourism accommodation industry of Wulingyuan from an unplanned, disordered, and homogeneous development mode to a more sustainable development mode. Such a transformation can be explained in two aspects. On one hand, the design of formal institutions achieves continuous improvement by interacting with informal institutions. Formal institutions become more detailed and complete, and the local government can cope with different situations by following them. On the other hand, legitimacy and justifiability of formal institutions is gained by aligning with upper level formal institutions, which empowers formal institutions to adjust behaviors guided by short-term economic interests. To this end, it is concluded that the sustainable development of the tourism accommodation industry needs the synergy of formal and informal institutions.

\section{Conclusions}

In contrast to a static view on tourism institutional embeddedness in previous studies, this paper takes a longitudinal and dynamic perspective on institutional embeddedness to explore the impacts of institutions on tourism accommodation format evolution in Wulingyuan. This study contributes to tourism institution studies by not only exploring the internal structure of formal and informal institutions, but also examining the interaction between formal and informal institutions.

While this is a place-specific study, its practical implications go beyond Wulingyuan. First, few formal institutions can be perfectly designed. This study suggests that local government can minimize 
the impacts of institutional loopholes by scaling up local formal institutions to fit with upper-level institutions, which bestows local formal institutions more solid authority to distract the attention of opportunists. Second, in countries like China where development is essentially state-led due to the existence of a powerful and centralized government, formal institutions can sometimes be so powerful that the balance between formal and informal institutions can be broken, obstructing further development. The experience of Wulingyuan shows that cultivating nongovernmental and civil forces (e.g., entrepreneurs associations) can be a way out of the problem [53,54]. Third, this study illustrates that the evolution of tourism accommodation format in Wulingyuan is closely related to the interaction between formal and informal institutions. When the relation of these two types of institutions changes fundamentally, significant format change is likely to happen, as illustrated by format update at the two institutional transition nodes in this study. Therefore, to facilitate tourism (accommodation) format update via proper institutional design, format evolution should be closely monitored, and key institutional transition nodes should be identified.

This research also has some implications for future studies. First, the analysis framework of institutional embeddedness does not include other influencing factors that may work in tourism accommodation format evolution. Further studies may take this study as a point of departure to analyze the evolution of different types of accommodation formats in different contexts [55], and take market demand, business strategy [56], hotel chains [57], and other factors [58] into consideration. Second, the paper only focuses on institutional embeddedness. Future studies can explore the effects of other types of embeddedness, such as relational embeddedness [13], on the tourism accommodation industry. Last but not least, a qualitative approach is adopted for this study due to its exploratory nature; future studies may verify the relationships among institutional clusters via quantitative methods.

Author Contributions: T.J. contributed to conceptualization, data analysis, draft paper review, and revision. S.Z. contributed to conceptualization, data collection and analysis, and draft paper writing. C.Z. contributed to research proposal, accessibility of the research case, and discussion about the research. J.G. contributed to review and editing, and revision.

Funding: This research was supported by the National Natural Science Foundation of China (grant number 41471122).

Conflicts of Interest: The authors declare no conflict of interest.

\section{References}

1. Wang, C.; Pawlowicz, R. Planning for the inevitable: An examination of strategic crisis planning in the Australian accommodation industry. Crisis Plan. 2011, 9, 1-5.

2. Adeola, O. Human capital development in the hospitality industry in Nigeria. Worldw. Hosp. Tour. 2016, 8, 149-157. [CrossRef]

3. Cai, L.A.; Zhang, L.; Pearson, T.E.; Bai, X. Challenges for China's state-run hotels. J. Hosp. Leis. Mark. 2000, 7, 29-46. [CrossRef]

4. Semone, P. A case study: Enhancing Lao's tourism sector performance through destination human resource development. Asia Pac. J. Tour. Res. 2012, 17, 164-176. [CrossRef]

5. Zhang, C.Z.; Xiao, H.G. Destination development in China: Towards an effective model of explanation. J. Sustain. Tour. 2014, 22, 214-233. [CrossRef]

6. Karhunen, P. Managing international business operations in a changing institutional context: The case of the St. Petersburg hotel industry. J. Int. Manag. 2008, 14, 28-45. [CrossRef]

7. O'Mahony, G.B.; Clark, I.D. From inns to hotels: The evolution of public houses in Colonial. Int. J. Contemp. Hosp. Manag. 2013, 25, 172-186.

8. McLennan, C.J.; Ritchie, B.W.; Ruhanen, L.M.; Moyle, B.D. An institutional assessment of three local government-level tourism destinations at different stages of the transformation process. Tour. Manag. 2014, 41, 107-118. [CrossRef]

9. Coase, R.H.; Alchain, A.; North, D. Property Rights and Institutional Change, 1st ed.; SDX Joint Publishing Company of Shanghai: Shanghai, China, 1994. (In Chinese) 
10. Wang, N. The Institutional Embeddedness in Customer Behaviors in Urban China, 1st ed.; Social Science Academic Press: Beijing, China, 2014. (In Chinese)

11. Xiong, Y.B.; Liu, H.Y. Study on the system arrangement of sustainable tourism development-A case study of Jiuzhaigou. Wuhan Univ. J. (Philos. Soc. Sci.) 2012, 65, 132-137. (In Chinese)

12. Polanyi, K. The Great Transformation, 1st ed.; Beacon Press: Boston, MA, USA, 1957.

13. Granovetter, M. Economic action and social structure: The problem of embeddedness. Am. J. Sociol. 1985, 91, 481-510. [CrossRef]

14. Nee, V.; Ingram, P. Embeddedness and beyond: Institutions, exchange and social structure. In The New Institutionalism in Sociology, 1st ed.; Briton, M.C., Nee, V., Eds.; Russell Sage Foundation: New York, NY, USA, 1998; pp. 19-45.

15. Zukin, S.; DiMaggio, P. Introduction to Structures of Capital, 1st ed.; Cambridge University Press: Cambridge, UK, 1990.

16. Briton, M.C.; Kariya, T. Institutional embeddedness in Japanese labor markets. In The New Institutionalism in Sociology, 1st ed.; Brinton, M.C., Nee, V., Eds.; California Stanford University Press: Stanford, CA, USA, 1998; pp. 181-207.

17. Jellema, J.; Roland, G. Institutional clusters and economic performance. J. Econ. Behav. Organ. 2011, 79, 108-132. [CrossRef]

18. Di Tella, R.; MacCulloch, R. Partisan social happiness. Rev. Econ. Stud. 2005, 72, 367-393. [CrossRef]

19. Cawley, M.; Marsat, J.B.; Gillmor, D.A. Promoting integrated rural tourism: Comparative perspectives on institutional networking in France and Ireland. Tour. Geogr. 2007, 9, 405-420. [CrossRef]

20. Brousseau, E.; Garrouste, P.; Raynaud, E. Institutional changes: Alternative theories and consequences for institutional design. J. Econ. Behav. Organ. 2011, 79, 3-19. [CrossRef]

21. North, D.C. Institutions. J. Econ. Perspect. 1991, 5, 97-112. [CrossRef]

22. Aoki, M. Toward a Comparative Institutional Analysis, 1st ed.; The MIT Press: Cambridge, UK, 2001.

23. Li, G.Y. The difference and connection of formal and informal institutions. Law Soc. Dev. 2009, 3, $146-152$. (In Chinese)

24. Tang, S.X. Informal Institutional Economics, 1st ed.; Shandong University Press: Jinan, China, 2011. (In Chinese)

25. Lin, J.Y. An economic theory of institutional change: Induced and imposed change. Cato J. 1989, 9, 1-33.

26. Williamson, O.E. Transaction Cost Economics and Organization Theory. In The Handbook of Economic Sociology, 2nd ed.; Smelser, J.N., Swedberg, R., Eds.; Princeton University Press: Princeton, NJ, USA, 1994; pp. 77-107.

27. Nee, V. The new institutionalism in economics and sociology. In The Handbook of Economic Sociology, 2nd ed.; Smelser, J.N., Swedberg, R., Eds.; Princeton University Press: Princeton, NJ, USA, 2005; pp. 49-74.

28. Li, H.M.; Gu, H.M. Theoretical research on hotel business development. In Hotel Industry: Theory and Practice, 1st ed.; Gu, H.M., Ed.; China Tourism Press: Beijing, China, 2011; pp. 3-32. (In Chinese)

29. Gu, H.M.; Ryan, C.; Yu, L. The changing structure of the Chinese hotel industry: 1980-2012. Tour. Manag. Perspect. 2012, 4, 56-63. [CrossRef]

30. Minazzi, R. Hotel classification systems: A comparison of international case studies. Acta Univ. Danub. OEconomica 2010, 6, 64-86.

31. Medlik, S.; Ingram, H. The Business of Hotels, 4th ed.; Butterworth-Heinemann: Oxford, UK, 2000.

32. Lamers, M. Heading into uncharted territory? Exploring the institutional robustness of self-regulation in the Antarctic tourism sector. J. Sustain. Tour. 2009, 17, 411-430.

33. Qu, R.; Ennew, C.; Sinclair, M.T. The impact of regulation and ownership structure on market orientation in the tourism industry in China. Tour. Manag. 2005, 26, 939-950. [CrossRef]

34. Sofield, T.; Li, S. Tourism management development and cultural policies in China. Ann. Tour. Res. 1998, 25, 362-392. [CrossRef]

35. Yasarata, M.; Altinay, L.; Burns, P.; Okumus, F. Politics and sustainable tourism development-can they co-exist? Voices from north Cyprus. Tour. Manag. 2010, 31, 345-356. [CrossRef]

36. Pine, R. China's hotel industry: Serving a massive market. Cornell Hotel Restaur. Adm. Q. 2002, 43, 61-70. [CrossRef]

37. Pine, R.; Qi, P. Barriers to hotel chain development in China. Int. J. Contemp. Hosp. Manag. 2004, 16, 37-44. [CrossRef]

38. Xu, H.G.; Zhang, C.Z.; Lew, A.A. Tourism geography research in China: Institutional perspectives on community tourism development. Tour. Geogr. 2014, 16, 711-716. [CrossRef] 
39. Wang, H.; Zheng, Y.F. Tourism participation of rural communities at the heritage sites in the perspective of institutional embeddedness: A comparative study of Yaotang village and Duanshi village in the Danxia Mountain. Geogr. Res. 2016, 35, 1164-1176. (In Chinese)

40. Khanna, T.; Yafeh, Y. Business groups in emerging markets: Paragons or parasites? J. Econ. Lit. 2007, 45, 331-372. [CrossRef]

41. Naughton, B.J. The Chinese Economy: Transitions and Growth, 1st ed.; The MIT Press: Cambridge, UK, 2007.

42. Sofield, T.; Li, S. Tourism governance and sustainable national development in China: A macro-level synthesis. J. Sustain. Tour. 2011, 19, 501-534. [CrossRef]

43. Gao, J.; Zhang, C.Z.; Liu, L. Communicating the outstanding universal value of World Heritage in China? The tour guides' perspective. Asia Pac. J. Tour. Res. 2019. [CrossRef]

44. Elo, S.; Kyngas, H. The qualitative content analysis process. J. Adv. Nurs. 2008, 62, 107-115. [CrossRef]

45. Ye, F.; Zhang, L.; Li, Y. Strategic choice of sales channel and business model for the hotel supply chain. J. Retail. 2018, 94, 33-44. [CrossRef]

46. Luo, Z.; Wang, Y.; Marnburg, E. Testing the structure and effects of full range leadership theory in the context of China's hotel industry. J. Hosp. Mark. Manag. 2013, 22, 656-677. [CrossRef]

47. Zhang, Q. Institutional embeddedness renewal or overembeddedness: The case of business groups in China. Asia-Pac. J. Bus. Adm. 2014, 6, 148-167. [CrossRef]

48. Santos, R.A.; Mexas, M.P.; Meirin, M.J. Sustainability and hotel business: Criteria for holistic, integrated and participative development. J. Clean. Prod. 2017, 142, 217-224. [CrossRef]

49. Chang, J. Introduction: Entrepreneurship in tourism and hospitality: The role of SMEs. Asia Pac. J. Tour. Res. 2011, 16, 467-469. [CrossRef]

50. Brousseau, E.; Raynaud, E. "Climbing the hierarchical ladders of rules": A life-cycle theory of institutional evolution. J. Econ. Behav. Organ. 2011, 79, 65-79. [CrossRef]

51. Peng, M.W.; Lee, S.H.; Wang, D. What determines the scope of the firm over time? A focus on institutional relatedness. Acad. Manag. Rev. 2005, 30, 622-633. [CrossRef]

52. Yang, C.Y. Study on the vicissitude mechanism of managerial institution of China's tourism industry and the construction of multiple dynamic game model. Tour. Trib. 2011, 26, 12-20. (In Chinese)

53. Horng, J.S.; Liu, C.H.; Chou, S.F.; Tsai, C.Y. From innovation to sustainability: Sustainability innovations of eco-friendly hotels in Taiwan. Int. J. Hosp. Manag. 2017, 63, 44-52. [CrossRef]

54. Zhang, C.Z.; Xiao, H.G.; Gursoy, D.; Rao, Y. Tacit knowledge spillover and sustainability in destination development. J. Sustain. Tour. 2015, 23, 1029-1048. [CrossRef]

55. Luo, J.M.; Lam, C.F. A qualitative study of urbanization effects on hotel development. J. Hosp. Tour. Manag. 2016, 29, 135-142. [CrossRef]

56. González-Rodríguez, M.R.; Jiménez-Caballero, J.L.; Martín-Samper, R.C.; Köseoglu, M.A.; Okumus, F. Revisiting the link between business strategy and performance: Evidence from hotels. Int. J. Hosp. Manag. 2018, 72, 21-31. [CrossRef]

57. Chen, L.F. Hotel chain affiliation as an environmental performance strategy for luxury hotels. Int. J. Hosp. Manag. 2019, 77, 1-6. [CrossRef]

58. Chan, J.K.L.; Quah, W.B. Start-up factors for small and medium-sized accommodation businesses in Sabah, Malaysia: Push and pull factors. Asia Pac. J. Tour. Res. 2012, 17, 49-62. [CrossRef]

(C) 2019 by the authors. Licensee MDPI, Basel, Switzerland. This article is an open access article distributed under the terms and conditions of the Creative Commons Attribution (CC BY) license (http://creativecommons.org/licenses/by/4.0/). 